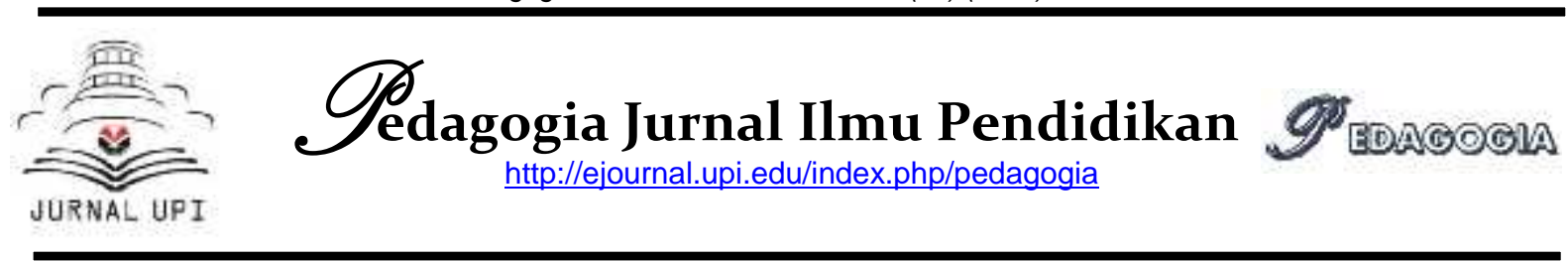

\title{
Efektivitas Manajemen Mutu Pembelajaran Guru Bidang Produktif di Sekolah Menengah Kejuruan
}

\author{
Endang Herawan \\ Suryadi \\ Departemen Administrasi Pendidikan \\ Fakultas Ilmu Penddikan \\ Universitas Pendidikan Indonesia \\ endangherawan@upi.edu
}

\begin{abstract}
A b s tract
This research is important because SMK teachers are the spearhead in learning in schools, where teachers are given authority in developing curriculum or learning programs. This study aims to analyze the effectiveness of the quality management of learning undertaken by teachers supporting productive subject groups in the Vocational Group in Business and Management Skills. This study uses a descriptive analytic approach with qualitative methods. Respondents in this study were the Principal, Head of Expertise Competency, Teachers at SMKN 1 Bandung and SMKN 3 Bandung. The results show: First, the paradigms used in curriculum development in these two State Vocational Schools are demand / market driven and life skills. Second, the implementation of education uses a dual system (PSG). Third, evaluation of learning conducted by the teacher of productive subject groups is carried out thoroughly covering the aspects of knowledge, attitudes and skills in each substantive learned. Fourth, the follow-up of the evaluation activities carried out by the productive sector teacher, the preparation of learning outcomes reports is carried out to improve the learning process, help students who have not yet achieved competency through remedial learning and enrichment.
\end{abstract}

Keywords: Effectiveness, Quality Management, Learning, Productive Teachers

\begin{abstract}
A bstrak
Penelitian ini penting dilakukan karena guru SMK sebagai ujung tombak dalam pembelajaran di sekolah, dimana guru diberikan kewenangan dalam mengembangkan kurikulum atau program pembelajaran. Penelitian ini bertujuan untuk menganalisis efektivitas manajemen mutu pembelajaran yang dilakukan oleh guru pengampu mata pelajaran rumpun bidang produktif pada SMK Kelompok Bidang Keahlian Bisnis dan Manajemen. Penelitian ini menggunakan pendekatan deskriptif analitik dengan metode kualitatif. Responden dalam penelitian ini adalah Kepala Sekolah, Ketua Kompetensi Keahlian, Guru-guru di SMKN 1 Bandung dan SMKN 3 Bandung. Hasil penelitian menunjukkan : Pertama, paradigma yang digunakan dalam pengembangan kurikulum pada ke dua SMK Negeri ini adalah demand/market driven dan life skills. Kedua, pelaksanaan pendidikan menggunakan sistem ganda (PSG). Ketiga, evaluasi Pembelajaran yang dilakukan oleh Guru kelompok Mata Pelajaran produktif dilaksanakan secara menyeluruh yang meliputi aspek pengetahuan, sikap dan keterampilan pada setiap substantif yang dipelajari. Keempat, tindak lanjut dari kegiatan evaluasi yang dilakukan oleh guru bidang produktif, penyusunan laporan hasil belajar dilakukan untuk memperbaiki proses pembelajaran, membantu siswa yang belum mencapai kompetensi melalui pembelajaran remedial dan pengayaan.
\end{abstract}

Kata Kunci: Efektivitas, Manajemen Mutu, Pembelajaran, Guru Produktif

\begin{tabular}{l}
\hline Article Info \\
\hline Naskah Diterima: \\
2019-07-20 \\
Naskah Direvisi: \\
2019-09-08 \\
Naskah Disetujui: \\
2019-10-12 \\
\hline
\end{tabular}

Kata Kunci: Efektivitas, Manajemen Mutu, Pembelajaran, Guru Produktif 


\section{A. PENDAHULUAN}

SMK merupakan lembaga pendidikan kejuruan yang bertujuan untuk meningkatkan pengetahuan dan keterampilan siswa, untuk menyiapkan tenaga kerja tingkat menengah yang terampil, terdidik, dan profesional, serta mampu mengembangkan diri sejalan dengan perkembangan ilmu pengetahuan dan teknologi dan seni (IPTEKS). Pendidikan kejuruan diberikan peran untuk menghasilkan manusia yang produktif, yakni manausia kerja, bukan manusia beban bagi keluarganya, masyarakat dan bangsanya, dengan demikian pendidikan kejuruan harus selalu terkait dengan produktivitas (Supriadi, 2002, Suharsimi 1988). Dengan demikian pendidikan kejuruan merupakan program yang secara langsung dikaitkan dengn penyiapan seseorang untuk suatu pekerjaan tertentu. Dalam pelaksanaannya pendidikan kejuruan masih menunjukkan adanya kelemahan pada konsep maupun pelaksanaannya, hal ini tampak kelihatan belum mampu menghasilkan lulusan yang siap kerja dan yang dapat memuaskan pelanggan khususnya dunia industri (Sukmadinata, 2006). Karena itu isu penting yang harus selalu dikedepankan dalam konteks penyelenggaraan pendidikan di SMK ini adalah seberapa besar penyelenggaraan pendidikan kejuruan (SMK) sejalan dan relevan dengan kebutuhan masyarakat, terutama kebutuhan tenaga kerja, dunia usaha maupun industri.

$$
\text { Pendidikan kejuruan yang }
$$

dilaksanakan melalui SMK saat ini cenderung masih terpisah dari dunia nyata karena, hal ini karena SMK masih merupakan sistem pendidikan persekolahan yang bersifat konservtif dan tidak mudah berubah seiring dengan perubahan dan perkembangan teknologi yang semakin pesat. Gejala "mismatch" antara lembaga pendidikan dan pelatihan kejuruan dengan dunia usaha/industri, pada akhirnya melahirkan lulusan "underqualified". Menurut Gatot Heri dan Giri Suryatmana (dalam Supriad 2002, hlm 603). Kondisi tersebut ditandai dengan struktur tenaga kerja Indonesia masih didominasi oleh pekerja kurang terdidik, penyiapan tenaga kerja tingkat menengah seakan-akan hanya menjadi tugas dan dilakukan oleh SMK, tingkat pengangguran tamatan sekolah menengah sebesar $12 \%$ untuk tamatan SMK dan $18 \%$ untuk tamatan SMU dan penguasaan kompetensi dan produktivitas tenaga kerja di Indonesia masih rendah dibandingkan tenaga kerja negara lainnya di kawasan Asia Tenggara, sehingga tenaga kerja Indonesia sulit bersaing, bahkan tidak sedikit peluang pekerjaan yang ada di Indonesia sendiri diisi oleh pekerja asing.

Keadaan seperti ini sudah cukup lama terjadi, bahkan sampai saat ini. Gejala ini merupakan permasalahan pendidikan dan mutu dan relevansi (Tilaar, 1998). Akar persoalan tersebut tidak lepas dari pengelolaan sekolah yang salah satu diantaranya terkait dengan proses pembejaran. Persoalan yang terkait dengan proses pembelajaran ada kaitannya dengan komitment dan kinerja guru. Persoalan yang utama dalam pembelajaran adalah bagaimana guru dapat mengelola agar pembelajaran yang dilaksanakannya itu bermutu, hal ini penting menjadi komitmen para guru, karena sekalipun kurikulum sudah dilakukan perubahan kearah yang lebih baik serta fasilitas pendidikan yang lengkap tidak akan memberikan dampak yang berarti pada peningkatan mutu pendidikan kalau tidak didukung oleh kinerja guru yang baik, yang mampu mewujudkan proses pembelajaran yang bermutu. Pembelajaran akan bermutu apabila guru mampu melakukan 
manajemen mutu terhadap kegiatan pembelajaran yang dilakukannya.

Manajemen mutu diimplementasikan dalam kegiatan pembelajaran agar proses dan hasil belajar siswa menjadi berkualitas. Lebih lanjut Tjiptono (2001) mengemukakan untuk menghasilkan mutu terbaik diperlukan upaya perbaikan berkesinambungan terhadap kemampuan manusia, proses, dan lingkungan. Depdiknas (2001) menegaskan bahwa agar dapat menjawab tantangan permasalahan ketenagakerjaan diperlukan lembaga pendidikan kejuruan yang handal dan mampu menerapkan manajemen mutu.

Dilandasi oleh permasalahan di atas peneliti terdorong untuk melakukan penelitian dengan maksud ingin memperoleh gambaran tentang manajemen mutu pembelajaran sebagai upaya untuk menghasilkan lulusan yang memiliki kemampuan yang sesuai dengan kebutuhan dunia usaha dan industri.

\section{B. TINJ AUAN PUSTAKA}

\section{Manajemen Mutu}

Manajemen mutu merupakan kegiatan yang diarahkan dalam upaya memenuhi kebutuhan konsumen secara konsisten dan mencapai peningkatan secara terus menerus dalam setiap aspek organisasi. Kegiatan dalam manajemen mutu tercermin dalam perbaikan terusmenerus untuk memenuhi kepuasan pelanggan, kerja sama, fokus pada pelanggan, berpikir jangka panjang dan pengambilan keputusan berbasis data. Menurut Gaspersz (2005) dan Fitzgerald (2007) pada dasarnya manajemen mutu terpadu sebagai philosophy dan sebagai suatu cara meningkatkan performansi secara terus-menerus pada setiap level operasi dan proses, dalam setiap area fungsional dari suatu organisasi, dengan menggunakan sumber daya manusia dan modal yang tersedia.
Lebih lanjut Gaspersz (2005) mengemukakan manajemen mutu dapat dikatakan sebagai semua aktivitas dari fungsi manajemen secara keseluruhan yang menentukan kebijaksanaan mutu, tujuan dan tanggungjawab, serta mengimplementasikannya melalui alat-alat manajemen mutu, seperti perencanaan mutu, pengendalian mutu, penjaminan mutu, dan peningkatan mutu. Seluruh kegiatan dalam manajemen mutu semuanya ditujukan agar proses dan produk yang dihasilkan dapat memenuhi kebutuhan dan harapan pelanggan.

Mukhopadyay (2005, hlm 27) mengemukakan "quality management has been defined as a set of concepts, strategies, tools and beliefs.etc., which are aimed at improving the quality of products and services reducing the waste and saving costs." Ada juga yang menyatakan manajemen mutu sebagai kegiatan yang dilakukan manajer dalam melaksanakan kebijakan mutu, hal ini seperti dikemukakan oleh Gueorguiev (2006) "quality management includes all the activities that managers carry out in an effort to implement their quality policy. These activities include quality planning, quality control, quality assurance, and quality improvement. Dengan demikian pada dasarnya manajemen mutu merupakan upaya untuk mengorganisir kegiatan yang dilakukan oleh orang-orang agar berjalan secara harmonis, lebih efektif dan efisien, dalam hal ini Tribus (2007, hlm 2) menyatakan "quality management is a different way to organize the effort of people. The objective is to harmonize their effort in such a way that not only do people approach their assigned tasks enthusiasm, but participate in improvement of how the gets done."

Dalam melaksanakan manajemen mutu suatu organisasi harus menganut filosofi membuat segala sesuatu dengan baik sejak dari awal proses hingga akhir proses produksi. Hal inilah yang mendasari konsep zero defect yang dikenal dalam manajemen mutu. Philip Crosby (dalam 
Lindsay dan Petrick, 1997) memperkenalkan empat filosofi manajemen mutu yaitu : (1) The definition of quality is conformance to requirement,(2) The system of quality is prevention of problems, (3) The performance standard of quality is zero defect, and (4) The measurement of quality is the price of nonconformance, or the of cost quality.

Manajemen mutu berorientasi pada proses yang mengintegrasikan semua sumber daya manusia, suppliers, dan para pelanggan di lingkungan lembaga. Hal ini berarti bahwa manajemen mutu berhubungan dengan kemampuan, pendelegasian kekuasaan tanggung jawab pada sumber daya manusia serta merupakan proses yang dapat dikontrol, dan bukan sesuatu yang kebetulan.

Manajemen mutu perlu dilakukan terhadap seluruh kegiatan sekolah, termasuk terhadap masalah pembelajaran, karena pembelajaran akan bermutu apabila ada upaya yang dilakukan secara sistematis oleh guru, mulai dari merencanakan, pelaksanaan dan evaluasi pembelajaran yang keseluruhannya selalu dikaitkan dengan kebutuhan dan harapan pelanggan.

\section{Mutu Pembelajaran}

Kata pembelajaran terkandung dua kegiatan yaitu belajar dan mengajar. Kegiatan yang berkaitan dengan upaya membelajarkan siswa agar berkembang potensi intelektual yang ada pada dirinya. Ini berarti bahwa pembelajaran menuntut terjadinya komunikasi antara dua arah atau dua pihak yaitu pihak yang mengajar yaitu guru sebagai pendidik dengan pihak yang belajar yaitu siswa sebagai peserta didik. Pada hakekatnya pembelajaran adalah proses interaksi peserta didik dengan pendidik dan sumber belajar pada suatu lingkungan belajar yang terarah pada tujuan pembelajaran yang telah ditentukan yaitu terjadi perubahan perilaku ke arah yang lebih baik (E.Mulyasa,2002, hlm 100, Sudirwo, 2002, hlm 31).
Mutu pembelajaran dapat dikatakan sebagai gambaran mengenai baikburuknya hasil yang dicapai oleh peserta didik dalam proses pembelajaran yang dilaksanakan. Sekolah dianggap bermutu bila berhasil mengubah sikap, perilaku dan keterampilan peserta didik dikaitkan dengan tujuan pendidikannya. Menurut Muljono (2006, hlm 29) bahwa konsep mutu pembelajaran mengandung lima rujukan, yaitu kesesuaian, daya tarik, efektivitas, efisiensi dan produktivitas pembelajaran.

\section{METODE PENELITIAN}

Metode penelitian yang digunakan dalam penelitian ini adalah metode kualitatif. Penelitian yang dilakukan berangkat dari permasalahan dalam lingkungan peristiwa yang sedang berlangsung dan bisa diamati serta diverifikasi secara nyata pada saat berlangsungnya penelitian. Peristiwaperistiwa yang diamati dalam konteks upaya peningkatan mutu dan relevansi pendidikan, yang dilaksanakan pengelola sekolah. Subjek penelitian antara ketua program keahlian, guru pengampu rumpun mata pelajaran bidang produktif.

Pengumpulan data dan informasi dengan menggunakan observasi dan wawancara mendalam (indepth), studi dokumentasi, rekaman dan foto. Ada beberapa tahap yang dilakukan oleh peneliti dalam melaksanaan penelitian kualitatif ini., yaitu tahap orientasi, tahap eksplorasi, dan tahap "member chek" . Sedangkan cara yang dapat ditempuh dalam analisis data, yaitu reduksi data, display" data, mengambil kesimpulan dan verifikasi.

\section{HASIL DAN PEMBAHASAN}

1. Rencana Pengembangan Program Pembelajaran di SMKN oleh Guru Mata Pelajaran Kelompok Produktif.

SMKN 1 dan SMKN 3 Bandung Untuk bidang bisnis manajemen memiliki 3 
jurusan atau program keahlian, yaitu Akuntansi, Administrasi Perkantoran, Pemasaran. Penyelenggaran pendidikan pada SMKN ini menggunakan kurikulum 2013 edisi revisi, Kurikulum pada SMK di bagi pada tiga kelompok, yaitu:

1. Kelompok Normatif, adalah mata pelajaran yang dialkokasikan secara tetap, yang meliputi pendidikan Agama, Kewargaannegara, Bahasa Indonsia, Pendidikan Jasmani, dan seni budaya.

2. Kelompok Adaptif terdiri atas mata pelajaran Bahasa Inggris, Matematika, IPA, IPS, Keterampilan Komputer dan Pengelolaan Informasi, dan Kewirausahaan.

3. Kelompok Produktif terdiri atas sejumlah mata pelajaran yang dikelompokkan dalam Dasar Kompetensi Kejuruan dan Kompetensi Kejuruan.

SMKN 1 dan 3 telah menetapkan suatu standar kompetensi yang disepakati bersama oleh pihak-pihak yang berkepentingan, tertutama dunia usaha/industri dan asosiasi profesi. Kompetensi tamatan SMK dirancang mengandung 3 komponen kompetensi yang merupakan kesatuan yang saling berkait dalam bentuk pribadi yang utuh para tamatan SMK Kompetensi tersebut meliputi kompetensi normatif, untuk membentuk kepribadian yang beriman dan bertaqwa, berbudi pekerti luhur, memiliki rasa tanggung jawab baik secara pribadi, sebagai pekerja, maupun sebagai anggota masyarakat bangsa Indonesia pada umumnya. Komponen kompetensi adaptif, berisi kemampuan-kemampuan yang dapat membekali tamatan dalam dalam mengembangkan dirinya, seperti kemampuan berkomunikasi dan memanfaatkan informasi, berpikir logis dan kritis, dan memiliki motivasi untuk selalu ingin maju. Komponen produktif, berisi kompetensi-kompetensi yang bersifat teknis (dalam bekerja) untuk masingmasing bidang keahlian.

Pengembangan kompetensi tersebut menjadi target sasaran bagi guru dalam melaksanakan pengembangan program pembelajarannya. Rencana atau program pembelajaran, berupa program semester, silabus maupun RPP. Khusus untuk Guru yang mengajar mata pelajaran kelompok produktif dalam pengembangan program pembelajaran diwujudkan dalam bentuk silabus dan RPP. Setiap guru diwajibkan menyusun program tahunan/semester, silabus, dan RPP. Khusus dalam mengembangkan RPP, para guru bidang produktif terlebih dahulu melakukan analisis terhadap kondisi siswa, sarana dan prasarana dan kompleksitas kegiatan. Sedangkan dalam mengembangkan kompetensi kejuruan mengacu pada SKKNI (Standar Kompetensi Kerja Nasional Indonesia ). Hal ini agar rumusan kompetensi yang yang dikembangkan oleh guru relevan dengan kebutuhan dunia kerja dan industri.

Program pembelajaran termasuk rumusan kompetensi yang sudah disusun oleh agar sesuai dengan kebutuhan dan harapan dunia usaha dan industri disinkronisasi dan divalidasi oleh pihak dunia kerja serta asosiasi profesi dan unsur Perguruan Tinggi, antara lain IAI (Ikatan Akutansi Indonesia) untuk program keahlian akutansi, Ikatan Sekretaris Indonesia (ISI) untuk program keahlian Administrasi Perkantoran, ASPRINDO (Asosiasi Perusahaan Ritel Indonesia) untuk program keahlian Pemasaran. Dalam validasi dan sinkronisasi tersebut pihak asosiasi profesi serta dunia usaha dan industri memberikan masukan terhadap rumusan kompetensi yang harus dimiliki oleh siswa SMK, materi pelajaran serta yang terkait soft skill, seperti: sikap, penampilan kerja, cara berpakaian dan etika kerja.

Mengingat perkembangan yang terjadi di dunia usaha/industri begitu cepat, setiap tahun atau dua tahun sekali program pembelajaran yang dikembangkan oleh guru secara rutin dilakukan pengkajian ulang pada awal tahun ajaran. Dengan dilakukan validasi dan sinkronisasi secara rutin diharapkan 
kurikulum tersebut tetap aktual, sehingga tamatan sekolah memiliki kemampuan dan kecakapan yang sesuai dengan perkembangan dan tuntutan dunia kerja. Dalam manajemen mutu hal ini penting dilakukan sehingga standar atau program yang ditetapkan sesuai dengan kebutuhan dan keinginan pelanggan (Dorothea, 2003, Arcaro, 2006). Kurikulum SMK perlu memperhatikan kebutuhan dunia kerja sebagaimana dikemukakan oleh Shoemaker (dalam Suharsimi, 1988, hlm 243) menyatakan "curriculum for vocational starts with a job and with the student on job".

Penyelenggakan pendidikan di SMKN 1 dan 3 mengunakan kurikulum 2013 yang dalam pengembangannya selalu memperhatikan demand/market driven. Hal ini mengingat sifat pendidikan kejuruan yang diarahkan untuk menyiapkan tenaga kerja, oleh karena itu perlu memperhatikan dan menyesuaikan dengan permintaan pasar. Karena itu kurikulum SMK selalu diupayakan agar selalu sesuai dengan kebutuhan, tantangan, dan dinamika dunia kerja. Hal tersebut mengindikasikan pendidikan kejuruan yang baik, hal seperti dikemukan oleh Kolde (1994) yang menyatakan bahwa program pendidikan kejuruan dalam pengembangannya harus dikaitkan dengan sector pribadi dan mendukung dunia usaha dan industri.

Dalam pengembangan kurikulum menggunakan beberapa pendekatan yang meliputi :

1. Pendekatan akademik.

2. Pendekatan kecakapan hidup.

3. Pendekatan kurikulum berbasis luas.

4. Pendekatan kurikulum berbasis kompetensi.

5. Pendekatan kurikulum berbasis pelatihan.

6. Pendekatan kurikulum berbasis produksi.

Pendekatan-pendekatan tersebut melandasi setiap guru pada setiap program keahlian yang ada di SMK dalam melaksanakan pengembangan program pembelajarannya, sehingga diharapkan lulusannya mampu bersaing di tingkat lokal, nasional bahkan tingkat internasional. Dengan didasarkan pada pendekatan tersebut kurikulum implementatif yang dikembangkan meliputi:

1. Cakupan bidang yang dikembangkan dan diajarkan pada siswa bersifat fleksibel menghadapi masa depan yang penuh dengan kemungkinan perubahan.

2. Memberikan dasar ilmu pengetahuan dan teknologi yang betul-betul dasar bagi pengembangan selanjutnya

3. Memberikan keterampilan secara mendasar dengan teknik kerja yang benar, sebagai dasar pengembangan profesi.

Dalam kurikulum SMKN 1 dan 3 kegiatan pembelajaran untuk program produktif, dilakukan di sekolah dan di dunia usaha/industri atau praktek kerja industri yang ditujukan bagi siswa kelas XI semester 4 selama 3 bulan, dengan jumlah jam pelajaran sebanyak 600 jam. Program ini perlu diberikan untuk memberikan pengalaman bekerja kepada siswa, sehingga ketika siswa tamat menyelesaikan pendidikan di sekolah, ia sudah memiliki pengalaman kerja, yang bisa dijadikan bekal dalam mencari pekerjaan.

Kompetensi siswa yang diharapkan dapat dikembangkan dalam program praktek kerja antara lain, untuk :

1. Program keahlian Akutansi

Bagi siswa yang menuntut ilmu pada program keahlian akutansi diharapkan memiliki pengetahuan dan keterampilan akutansi sehingga mampu mengelola usaha mandiri. Lapangan kerja yang dapat diisi adalah:

a. Tenaga akutansi perusahaan dagang dan jasa.

b. Tenaga akutansi perusahaan manufaktur dan,

c. Administrasi keuangan.

2. Program keahlian administrasi perkentoran 
Bagi siswa yang menuntut ilmu pada program keahlian adminstrasi perkantoran diharapkan memiliki pengetahuan dan keterampilan mengenai pengelolaan administrasi kantor, dengan lapangana kerja yang dapat diisi adalah:
a. Tenaga staf administrasi kantor.
b. Resepsionis.
c. Operator telefon.
d. Asisten sekretaris.

3. Program keahlian perdagangan

Bagi siswa yang menuntut ilmu pada program keahalian perdagangan diharapkan memiliki kompetensi pengelolaan perdagangan, dengan lapangan pekerjaan yang dapat diisi adalah :
a. Tenaga staf administrasi penjualan.
b. Operator mesin-mesin bisnis.
b. Pengurusan dokumen ekspor dan impor.
c. Pramuniaga.
d. Staf marketing.
e. Staf pergudangan.
f. Pembukuan penjualan.

Kompetensi yang dikembangkan dalam penyelenggaraan pendidikan di SMK Negeri 1 dan 3 Bandung, selain yang bersifat teknis, juga kemampuan non teknis yang mencakup dua hal, yaitu kemampuan-kemampuan perilaku normatif, baik sebagai pribadi, sebagai mahluk sosial, maupun sebagai mahluk tuhan, kedua kemampuan-kemampuan berperilaku yang mengarah pada pengembangan diri, baik dalam rangka peningkatan prestasi kerja di lingkungan maupun peningkatan kualifikasi pendidikannya.

\section{Pelaksanaan Program Pembelajaran Oleh Guru Mata Pelajaran Kelompok Produktif}

Sesuai dengan sifat pendidikan kejuruan yang lebih menekankan pada pengembangan keterampilan siswa, maka dalam mengimplementasikan program pembelajaran guru di SMKN 1 dan 3 menggunakan pendekatan scientific dan berbagai model pembelajaran antara lain: 1) Discovery learning. 2) Inquery Learning, 3) Problem Based Learning, 4). Project Based Learning dan 5) Production Based Training. Dalam pelaksanaan program pembelajaran, pihak sekolah juga mendatangkan guru tamu yang berasal dari dunia kerja. Contoh misalnya mendatangkan unsur perbankan kemudian dari Bursa Efek Jakarta.

Untuk pembelajaran mata pelajaran produktif lebih diarahkan pada kegiatan praktek, yang dalam pelaksaannya bisa dilakukan di kelas, laboraturium, unit usaha yang ada di sekolah atau fasilitas lain yang bisa dijadikan tempat belajar atau praktek siswa. Unit-unit usaha yang ada di sekolah, seperti di toko atau koperasi sekolah, laboratorium, kantor sekolah. Kegiatan pembelajaran untuk mata pelajaran produktif juga dilaksanakan di dunia usaha dan industri, baik instansi swasta maupun instansi pemerintah, dalam bentuk praktek kerja industri yang berlangsung selama 3 bulan bagi siswa kelas XI. Pengalaman belajar di dunia kerja penting bagi siswa sekolah kejuruan, karena dunia kerja sebagai sumber belajar, melalui belajar di dunia kerja siswa akan mendapatkan pengetahuan, keterampilan, sikap dan nilai-nilai dalam dunia kerja (Soeharto,1988, Wenrich,1988).

Kegiatan praktek kerja industri, merupakan suatu strategi pembelajaran keahlian atau keterampilan yang dirancang berdasarkan prosedur dan standar kerja yang sesungguhnya (real job) untuk menghasilkan barang dan jasa sesuai dengan tuntutan pasar atau konsumen. Dunia usaha industri dipilih untuk program praktek kerja disesuaikan dengan program keahlian dan diusahakan memilih dunia usaha/industri yang telah memiliki adminitrasi dan manajemen yang baik dan tertib (ada ijin usaha, struktur organisasi, memiliki peraturan kerja, dsb), lokasi dunia usaha berada di sekitar kota Bandung. Dalam melaksanakan kegiatan praktek kerja industri setiap siswa membawa buku Jurnal Kegiatan Siswa. 
Rangkaian kegiatan yang dilakukan sekolah dalam pelaksanaan praktek kerja industri antara lain:

1. Persiapan, meliputi persiapan yang bersifat administratif, rapat koordinasi dengan tim pelaksana, dan pertemuan dengan orang tua murid.

2. Pelaksanaan, meliputi pengarahan, pelepasan, penempatan tempat, pelaksanaan, pengumpulan data dan monitoring.

3. Evaluasi dan pelaporan, meliputi pelaksanaan ujian praktek kerja industri dan sertifikasi.

Untuk kelancarann program praktek kerja industri ini pihak sekolah melakukan kerjasama dengan beberapa dunia usaha/industri untuk menyusun dan menetapkan program praktek kerja industri dan bidang-bidang pekerjaan yang dibisa dikerjakan selama siswa praktek kerja industri. antara lain:

1. Bidang keahlian penjualan, bidang pekerjaanya, meliputi:

a. Melakukan penjualan barang dagangan, yang meliputi penjualan barang dagangan, sikap menjual dan pengenalan mekanisme penjualan.

b. Melakukan pembelian, meliputi pengenalan barang, pengenalan dan prosedur pembelian.

c. Pengelolaan perdagangan, meliputi penyediaan barang dan pendistribusian barang.

d. Penyajian penjualan barang, meliputi penataan dan pengenalan barang, penggolongan barang, penyusunan barang, pemeliharaan barang dan customer service.

e. Administrasi perdagangan, meliputi pencatatan transaksi pada buku penjualan, pencatatan transaksi pada bon penjualan, pengiriman dan pengembalian.

\section{Bidang keahlian administrasi perkantoran, bidang pekerjaannya meliputi :}

a. Pengurusan surat keluar, meliputi membuat dan pengetikan surat dan pengekspedisian surat keluar.

b. Pengurusan surat masuk, meliputi mencatat surat dan mendistribusikan surat.

c. Pengelolaan arsip, meliputi: pengurusana surat, penataan berkas dan penemuan kembali arsip.

d. Menangani telepon.

e. Penerimaan tamu.

f. Pengenalan dan pengoperasian mesin kantor (komputer, mesin tik, fax dan foto copy).

g. Pengelolaan administrasi barang, meliputi membuat konsep kebutuhan barang, pembukuan barang dan pelaporan administrasi barang.

h. Kegiatan keprotokolan.

i. Administrasi kepegawaian, meliputi perencanaan pegawai, pengadaan pegawai dan mutasi pegawai.

3. Bidang keahlian keuangan/akutansi, bidang pekerjaannya :

a. Pengenalan badan usaha tempat latihan.

b. Pengenalan sistem akutansi pada perusahaan/instansi tempat latihan.

c. Mengidentifikasi bukti transaksi.

d. Pencatatan transaksi, membuat laporan keuangan dan mengoperasikan komputer

e. Uji Kemampuan.

Dalam praktek kerja industri setiap siswa memiliki guru pembimbing dari sekolah dan pembimbing dari dunia usaha. Tugas utama guru pembimbing adalah mengadakan komunikasi dengan pembimbing dari dunia usaha dan memonitor kemajuan siswa di tempat kerja, memeriksa jurnal dan menerima laporan, masukan dan saran dari pembimbing 
yang ada di dunia usaha berkaitan dengan praktek kerja industri siswa. Sedangkan tugas pembimbing dari dunia kerja adalah menetukan kegiatan-kegiatan atau kemampuan-kemampuan yang dapat dipraktekan oleh siswa di dunia kerja, memberikan bimbingan dan pelatihan kepada siswa dalam bidang pekerjaan tertentu, membina masalah kedisiplinan, kemandirian, kerjasama, keterampilan dalam melakukan komunikasi dan memberikan penilaian atas hasil kerja siswa selama praktek dengan menggunakan format penilaian yang telah disediakan dalam buku jurnal praktek kerja industri siswa.

Dalam pelaksanakan praktek kerja industri senantiasa ada permasalahan, yaitu tidak semua kompetensi yang telah ditetapkan dalam jurnal praktek kerja industri atau bidang pekerjaan yang sudah digariskan dalam program pelatihan dapat direalisasikan, karena tidak setiap siswa mendapatkan atau diberikan kesempatan untuk melakukan kerja yang sesuai dengan pekerjaan yang dilakukan di dunia usaha/industri tersebut, atau karena kegiatan yang dilaksanakan di dunia usaha/industri tidak seluruhnya dapat mengaktualisasikan kegiatan/pekerjaan atau kompetensi yang telah ditetapkan dalam jurnal kegiatan praktek kerja industri. Sebagai akhir dari kegiatan praktek kerja industri ini, setiap siswa diwajibkan membuat laporan, dan sebagai bukti telah mengikuti praktek kerja industri setiap siswa mendapat sertifikat dari dunia usaha/industri.

\section{Evaluasi Pembelajaran yang dilakukan Guru Mata Pelajaran Produktif di SMK Negeri 1}

Evaluasi pembelajaran yang dilaksanakan oleh guru mengajar mata pelajaran kelompok Produktif di SMKN 1dan 3 bertujuan untuk mengetahui hasil belajar siswa sekaligus juga efektivitas proses pembelejaran. Evaluasi terhadap siswa dilaksanakan secara menyeluruh yang meliputi aspek pengetahuan, sikap dan keterampilan pada setiap substantif yang dipelajari. Penilaian pengetahuan dilakukan guru dalam bentuk tes tertulis, tes lisan, penugasan.

Penilaian keterampilan dilakukan melalui penilaian kinerja, dan penilaian proyek, kedua penilaian ini dilakukan mengukur capaian pembelajaran berupa keterampilan proses dan/atau hasil produk.

Penilaian yang dilakukan guru produktif di SMKN1 dan 3 dalam pembelajaran, dilakukan dalam bentuk:

1. Ulangan

Proses yang dilakukan untuk mengukur pencapaian kompetensi peserta didik secara berkelanjutan dalam proses pembelajaran untuk memantau kemajuan dan perbaikan hasil belajar peserta didik untuk setiap kompetensi dasar (KD).

2. UTS

Dilakukan guru untuk mengetahui pencapaian kompetensi peserta didik setelah melaksanakan 8-9 minggu kegiatan pembelajaran.

3. UAS

Dilakukan oleh guru untuk mengukur pencapaian kompetensi peserta didik diahir semester.

Bentuk soal yang umumnya dikembangkan oleh guru bidang produktif dalam bentuk kasus atau masalah yang berkaitan dengan suatu tugas atau pekerjaan Bentuk tes ini dilakukan karena untuk mengetahui tingkat kemapuan siswa (kompetensi) dalam memecahkan masalah atau dalam mengerjakan suatu tugas/pekerjaan yang sesuai dengan program keahliannnya.

Sedangkan untuk kegiatan praktek kerja industri penilaian dilakukan oleh guru pemimbing praktek kerja industri yang ada di tempat praktek siswa. Penilaian ini dilakukan selama siswa mengikuti praktek kerja industri, dengan menggunakan format yang dikembangkan sekolah dan telah diselaraskan dengan standar kerja yang berlaku di dunia usaha dan industri. Aspek lain yang dinilai dalam kegiatan 
praktek kerja industri ini adalah penilaian sikap dan kepribadian siswa selama melaksanakan praktek kerja, yang meliputi kejujuran, tanggung jawab, kedisiplinan, hubungan interpersonal, kerjasama, kemandirian, penampilan, kreatifitas kerja, etika kerja dan etos kerja.

\section{Bagaimanakah tindak lanjut dari kegiatan evaluasi yang dilakukan oleh Guru bidang produktif.}

Setiap selesai melakukan evaluasi hasil belajar, hasil jawaban siswa yang sudah dikoreksi dikembalikan kepada siswa, dalam lembar jawaban yang sudah dikoreksi diberikan catatan atau saran bagi siswa sebagi bahan perbaikan.

Kegiatan evaluasi yang dilakukan guru bukan hanya untuk mengetahui hasil belajar siswa atau kompetensi siswa, tetapi dijadikan dasar untuk melakukan perbaikan dan pengembangan kegiatan pembelajaran yang dilakukan guru. Hasil belajar siswa selain digunakan sebagai bahan penyusunan laporan kemajuan hasil belajar, juga dilakukan untuk memperbaiki proses pembelajaran melalui pembelajaran remedial dan pengayaan. Pembelajaran remedial dilakukan oleh guru bagi siswa yang belum mencapai SKM, yaitu 70 sampai 75 dengan cara pemberian pembelajaran ulang dan pemberian tugas atau latihan khusus, serta pemanfaatan tutor sebaya. Sedangkan pembelajaran pengayaan dilakukan melalui belajar kelompok di luar jam pelajaran, tugas atau belajar mandiri.

Dengan demikian hasil penilaian yang dilakukan oleh guru, baik dalam penilaian harian, ulangan, UTS maupun UAS, hasilnya bukan hanya menggambarkan kompetensi siswa, juga akan menjadi umpan balik bagi guru untuk melakukan peningkatan dan perbaikan dalam melaksanakan proses pembelajaran atau dalam bentuk layanan individual dan kelompok bagi siswa yang belum mencapai standar minimal. Dalam konteks manajemen mutu itu penting dilakukan oleh guru, sebagaimana dikemukakan oleh Sallis (2013) Hasil dari proses evaluasi harus dibicarakan dengan murid. Hal ini bertujuan untukmelengkapi hasil evaluasi.

\section{KESIMPULAN}

Secara umum guru-guru yang mengajar mata pelajaran kelompok produktif sudah melaksanakan manajemen mutu, hal ini meliputi proses merencakan program pembelajaran yang didasarkan atas analisis terhadap siswa, fasilitas sekolah dan aspek kompleksitas serta memperhatikan kebutuhan dan harapan dunia usaha dan industry. Kemudian dalam pelaksanaan pembelajaran konsisten dengan rencana pembelajaran yang disusun, menggunakan berbagai macam model pembelajaran yang memungkinkan pengetahuan dan keterampilan bisa berkembang dengan baik, pembelajaran dilaksanakan di sekolah dan di dunia kerja, yang menjadi masalah adalah dalam kegiatan praktek belum semua kompetensi yang ditetapkan bisa dikembangkan pada saat praktek kerja. Sedangkan evaluasi dilakukan secara menyeluruh, baik pengetahuan, sikap maupun keterampilan. Umpan balik terhadap hasil evaluasi, sebagai bahan untuk remedial dan pengayaan kepada siswa serta untuk perbaikan terhadap proses pembelajaran.

\section{DAFTAR PUSTAKA}

Arcaro,J. (2006). Pendidikan Berbasis Mutu. Yogyakarta : Pustaka Pelajar.

Ariani, W. Dorothea., (2003). Manajemen Kualitas. Cetakan pertama. Universitas Atma Jaya Yogyakarta.

Arikunto, S. (1988). Organisasi dan Administrasi : Pendidikan Teknologi dan Kejuruan. Jakarta : Rajawali. 
Depdiknas. (2001). Standar Pelayanan Minimal Penyelenggaraan Sekolah Menengah Kejuruan. Jakarta : Depdiknas.

Fitzgerald, R. (2007). Historic building record and the Halifax Borough Market doors. Industrial Archaeology Review, 29(1), 51-74.

Gaspersz, V. (2005). Total Q uality Control". Jakarta: Gramedia Pustaka Utama.

Gueorguiev, T. (2006). Quality management in higher education. Quality of higher education.Tersedia : http://qedu.uni-ruse.bg/2006/bg/accpapers/gueorguiev.pdf

Kolde, R. (1994). What Is Quality Vocational Education. Vocational Education J ournal, 69.

Lindsay, W. M., \& Petrick, J. A. (1997). Total Quality and Organization Development. Total Q uality Series. St. Lucie Press, 2000 Corporate Blvd., NW, Boca Raton, FL 33431-9868.

Mukhopadhayay, M. (2005). Total Quality Management in Education, Sage Publication.

Muljono, P. (2006). Standar Proses Pembelajaran. Jakarta: Buletin BSNP. Vol. I/No. 2/Mei

Mulyasa, E. (2002). Kurikulum Berbasis Kompetensi: Konsep, Karakteristik, dan Implementasi. Jakarta : Rosdakarya.

Sallis, E. (2006). Total Quality Management in Education. Yogyakarta: IRCiSoD.

Soeharto. (1988). Disain Instruksional : Sebuah Pendekatan Praktis untuk Pendidikan Teknologi dan Kejuruan. Jakarta : Depdikbud.

Sudirwo, D. (2002). Kurikulum dan pembelajaran dalam rangka otonomi daerah. Bandung : Andira.

Sukmadinata, N. S. (2006). Pengendalian Mutu Pendidikan Sekolah Menengah. Bandung: Refika Aditama.

Supriadi, D. (2002). Sejarah Pendidikan Teknik dan Kejuruan di Indonesia: Membangun Manusia Produktif. Depdiknas : Jakarta.

Tilaar, H. A. R. (2001). Manajemen Pendidikan Nasional. Bandung : Rosdakarya.

Tjiptono, F., \& Diana, A. (2000). TQ M: Total Quality Management. Yogyakarta: Andi.

Tribus, M. (2007). Quality Management in Education. ERIC Clearinghouse.

Wenrich, R. et. all (1988). Administration Vocational E ducation. American Technical Publisher, Inc. 